\title{
Plant Communities of Archaeological Sites, Abandoned Dwellings, and Trampled Tundra in the Eastern Canadian Arctic: A Multivariate Analysis
}

\author{
BRUCE C. FORBES ${ }^{1}$
}

(Received 27 April 1993; accepted in revised form 15 December 1995)

\begin{abstract}
Arctic terrestrial ecosystems subjected to anthropogenic disturbance return to their original state only slowly, if at all. Investigations of abandoned settlements on three islands in the eastern Canadian Arctic Archipelago have detected striking similarities among contemporary and ancient human settlements with regard to their effects on tundra vegetation and soils. Ordination procedures using 240 quadrats showed the plant assemblages of Thule (ca. 800 B.P.) winter dwellings on northern Devon and southern Cornwallis Islands to be floristically similar to pedestrian-trampled meadows on northeast Baffin Island last used ca. 1969. Comparisons from the literature made with other North American sites in the Low Arctic reveal similar findings. The implication is that the depauperate flora of the Arctic has a limited number of species able to respond to disturbance, and that anthropogenically disturbed patches may be extremely persistent.
\end{abstract}

Key words: Thule culture, phytoarchaeology, High Arctic, trampling, anthropogenic disturbance, growth forms, ordination

RÉSUMÉ. Les écosystèmes terrestres arctiques soumis à une perturbation anthropique ne retournent que lentement — lorsqu'ils le font - à leur état initial. Des études faites sur des établissements abandonnés dans trois îles de l'archipel Arctique canadien oriental ont permis de constater des ressemblances frappantes entre les établissements humains contemporains et anciens en ce qui concerne leurs effets sur la végétation et les sols de la toundra. Les procédures d'ordination portant sur 240 quadrats ont montré que les communautés végétales des habitations d'hiver de Thulé (v. 800 BP) situées dans le nord de l'île Devon et le sud de l'île Cornwallis, sont similaires au plan de la flore aux prairies piétinées par l'homme v. 1969 dans le nord-est de la terre de Baffin. Des comparaisons établies à partir de documentation réalisée sur d'autres sites nord-américains dans le Bas-Arctique révèlent des constatations similaires. L'implication est que la flore souffreteuse de l'Arctique possède un nombre limité d'espèces capables de réagir aux perturbations, et que les endroits perturbés anthropiquement pourraient demeurer tels quels très longtemps.

Mots clés: culture de Thulé, phytoarchéologie, Extrême-Arctique, dommages dus au piétinement, perturbation anthropique, formes de croissance, ordination

Traduit pour la revue Arctic par Nésida Loyer.

РЕЗЮМЕ. Наземные экосистемы Арктики, лодвергшиеся антрологенному нарушению, возвращаются в исходное состояние очень медленно, если таковое вообще происходит. Изучение локинутых лоселений на трех островах в заладной части Канадского Арктического Архилелага выявили крайнюю схо жесть современных и древних лоселений человека в отношении их влияния на тундровые лочвы и растительность. Ординация 240 лробных ллощадей локазала, что растительные ассоциации на месте зимовий культуры Туле (около 800 лет назад) на северном Девоне и южном Колнуэльсе флористически сходны с лугами на северо-востоке Баффиновой Земли, выталтывавшимися лешеходами вллоть до 1969 года. Сравнение с другими участками североамериканской Арктики, олисанными в литературе, лривело к сходным результатам. Из этого следует, что обедненная флора Арктики включает ограниченное количество видов, способных переносить нарушения, а антрологенные сообщества могут быть очень устойчивыми.

ключевые слова: культура Туле, фитоархеология, высокая Арктика, антрологенное нарушение, жизненные форм., ординация.

\section{INTRODUCTION}

It is often noted that Arctic ecosystems do not recover readily from even minor human impact (Ives, 1970; Dunbar, 1973; Banfield, 1975; Eckhardt, 1988), but there are few long-term data from the High Arctic to either support or refute this assumption. We should be able to detect evidence of human occupation through examination of vegetation and soils from long-abandoned occupation sites of relatively small size and low levels of impact. This has long been true in the Arctic and Subarctic, as well as in more temperate regions, and detection has been possible through both field surveys and remote

${ }^{1}$ Arctic Centre, University of Lapland, Box 122, SF-96101, Rovaniemi, Finland

(C) The Arctic Institute of North America 
sensing (Hrdlicka, 1937; Lutz, 1951; Harp, 1974; McCartney, 1979; Moore and Denton, 1988; Thannheiser, 1989; Brooks and Johannes, 1990). However, there has been little in the way of synthesis of geographically disjunct observations from arctic archaeological sites within what is acknowledged to be a region of floristic unity (Steere, 1953; Hultén and Fries, 1986; Walker et al., 1994). Reliably dated sites of anthropogenic disturbance provide the best opportunity to test hypotheses about long-term vegetation change and its relationship to human impact.

Human activity in the High Arctic, however minimal or local, often results directly in reductions in vegetation biomass, species richness, and growth form diversity. Typically, there are concomitant and persistent changes in soil structure, thermal regime, and hydrology, particularly in mesic habitats (Kevan, 1971; Babb and Bliss, 1974; Forbes, 1992a,b, 1994). The most common and widespread impacts, such as camping and trampling, are seemingly innocuous activities, yet actually have measurable effects on plants and soils (Bates, 1938; Monti and Mackintosh, 1979; Forbes, 1992b). Researchers in temperate and tropical regions have already pointed to regional and global floristic convergence as a result of such activities, although the species involved are often of Mediterranean European provenance (Frenkel, 1972; Ellenberg, 1988).

Data are presented on a variety of plant communities from widely disjunct sites in arctic Canada that are naturally recovering from anthropogenic impacts, and their floristic, edaphic and climatic relationships are discussed. The plant communities of archaeological sites on northern Devon and southern Cornwallis Islands are compared with those in areas of modern disturbances on northern Devon and northeastern Baffin Island.

\section{Description of the Study Sites}

The three study sites (Fig. 1) all lie on coastal lowlands within the $4^{\circ} \mathrm{C}$ (mean July temperature) bioclimatic zone (sensu Edlund, 1990), with local slopes ranging from $2-4.5^{\circ}$. The sampled vascular floras of the most extensively surveyed lowlands at Truelove Lowland, Devon Island $\left(75^{\circ} 33^{\prime} \mathrm{N}\right.$, $\left.84^{\circ} 40^{\prime} \mathrm{W}\right)$ and Clyde River, Baffin Island $\left(70^{\circ} 35^{\prime} \mathrm{N}, 68^{\circ} 40^{\prime} \mathrm{W}\right)$ share $82.5 \%$ of their taxa. However, the lowlands are of contrasting lithologies, and the bryophyte floras of these same sites share only $32 \%$ of their taxa. The surfaces adjacent to the sampled Thule dwellings at Truelove Lowland and Resolute Bay, Cornwallis Island $\left(74^{\circ} 41^{\prime} \mathrm{N}, 94^{\circ} 57^{\prime} \mathrm{W}\right)$ consist essentially of calcareous cobbles. Interstices collect some fine aeolian sand, silt, and organic matter from the minimal plant cover.

Four Thule dwellings were sampled in July 1990 on the north shore of Truelove Lowland (Federal Government site designations QkHn-10, QkHn-11, QkHn-12) and at an additional site near Resolute Bay (QeJu-2). All appear to have been winter dwellings of the structural type described by Schledermann (1976) and have been discussed from an archaeological perspective by Helmer (1991) and Schledermann and Nash (1977). The dates of occupation are

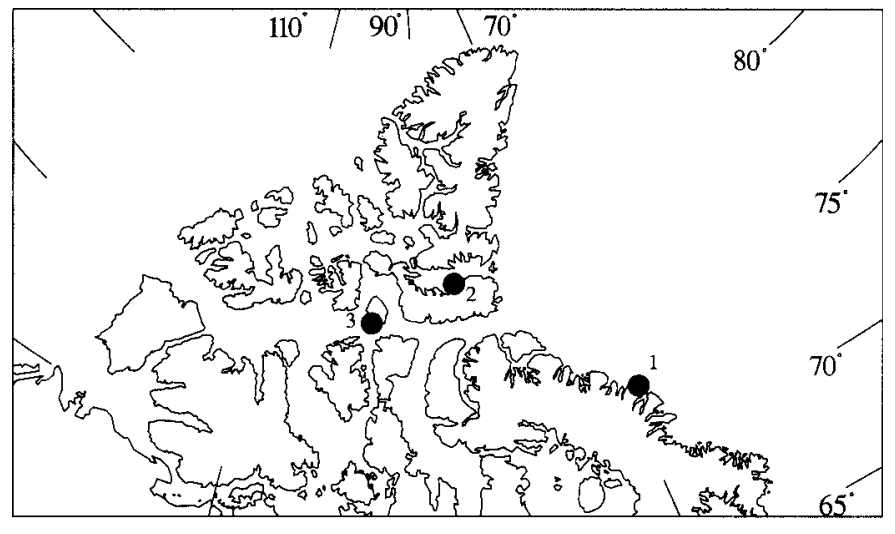

FIG. 1. Map of Canadian Arctic Archipelago showing the locations of the study sites. 1 = Resolute Bay, Cornwallis Island; 2 = Truelove Lowland, Devon Island; 3 = Clyde River, Baffin Island.

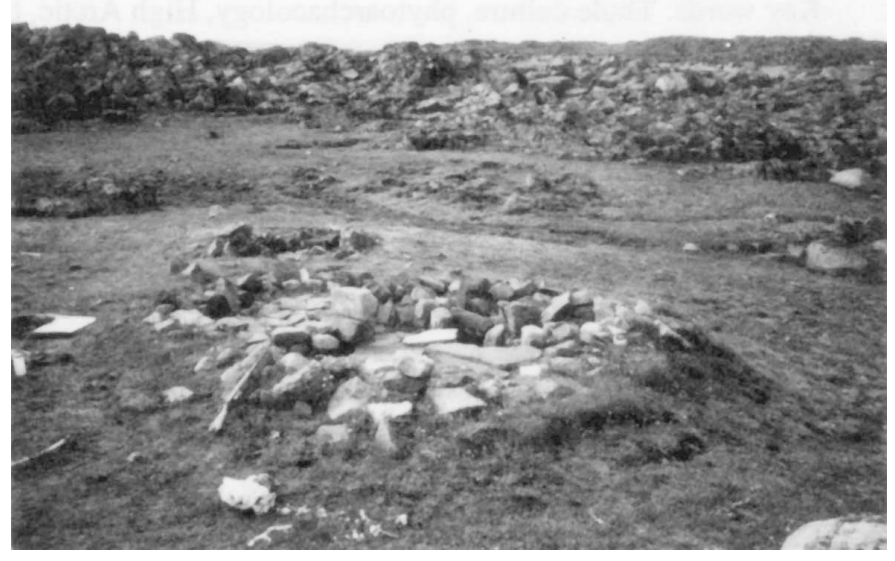

FIG. 2. General aspect of recently excavated (1986) Thule winter dwelling (foreground) and unexcavated dwelling (rear) on beach ridge at Truelove Lowland, Devon Island. Alopecurus alpinus was abundant on all three dwellings surveyed, but was most densely flowering and comprised by far the majority of the biomass on the recently excavated pad. Prominent flowers visible on the excavated dwelling are those of Papaver radicatum. The rifle leaning on wall at left gives scale. Photo date: 25 July 1990.

ambiguous for the Truelove Lowland sites, according to Helmer (1991), but the most recent date estimated for human usage is $800 \pm 180$ years B.P. (J.W. Helmer, pers. comm. 1992). The period of Thule whaling culture in the Canadian Arctic generally lasted from about 1100 A.D. to the historic period. One of the Truelove Lowland dwellings sampled (QkHn-12) was recently excavated, after which its stone foundation was reconstructed (Park, 1986) (Fig. 2).

The Thule dwellings at Resolute Bay and Truelove Lowland occur in polar semidesert vegetation types on dry, cobbly beach ridges of the kind described by Arkay (1972) and Svoboda (1977). The stands sampled at Truelove Lowland were similar to Svoboda's semidesert, but with lesser amounts of Dryas integrifolia (vascular nomenclature follows Porsild and Cody, 1980). Vascular cover was ca. 20\% and included mainly Salix arctica, Saxifraga oppositifolia, and Carex spp., with scattered forbs. Lichen cover was generally extensive, with Lecanora epibryon and Rhizocarpon geographicum being the most abundant (lichen nomenclature follows 
Thomson, 1990). Common moss genera included Bryum, Distichium, Ditrichum, Encalypta, Mnium, and Myurella (moss nomenclature follows Vitt, 1975).

The trampling disturbances, detailed floristics, and vegetation at Clyde River are described by Forbes (1992a,b, 1994). A number of small Inuit houses situated in Sphagnumdominated, hummocky sedge meadows were dismantled and removed in 1969. The four Inuit housepads examined at Clyde were of three construction types. No. 18 had no foundation; the house was laid on $8 \times 8 \times 97 \mathrm{~cm}$ wooden blocks directly on Sphagnum meadow. Nos. 4 and 7 had a two-layered foundation: $8 \mathrm{~cm}$ of sand on top of $11 \mathrm{~cm}$ of gravel spread directly on Sphagnum meadow. The houses were laid on $8 \times 8 \times 97 \mathrm{~cm}$ wooden blocks embedded in the sand layer. No. 19 had a foundation of sand and gravel fill in a wooden frame $16 \mathrm{~cm}$ high laid on the beach ridge.

The residences had been occupied for six years, with the result that the soil surface beneath the houses was devoid of above-ground biomass at the time of removal. The adjoining meadows were affected by pedestrian traffic during this period but had been left to recover for some 21 years at the time of sampling (Fig. 3). Interviews, airphoto analyses and field surveys revealed clear disturbance gradients. At the time of abandonment, bare, heavily trampled soils existed immediately adjacent to the houses. These graded to lightly trampled surfaces some 30 to $35 \mathrm{~m}$ distant, with naturally occurring vegetation and soils just beyond. The site has been unused since winter 1969-70.

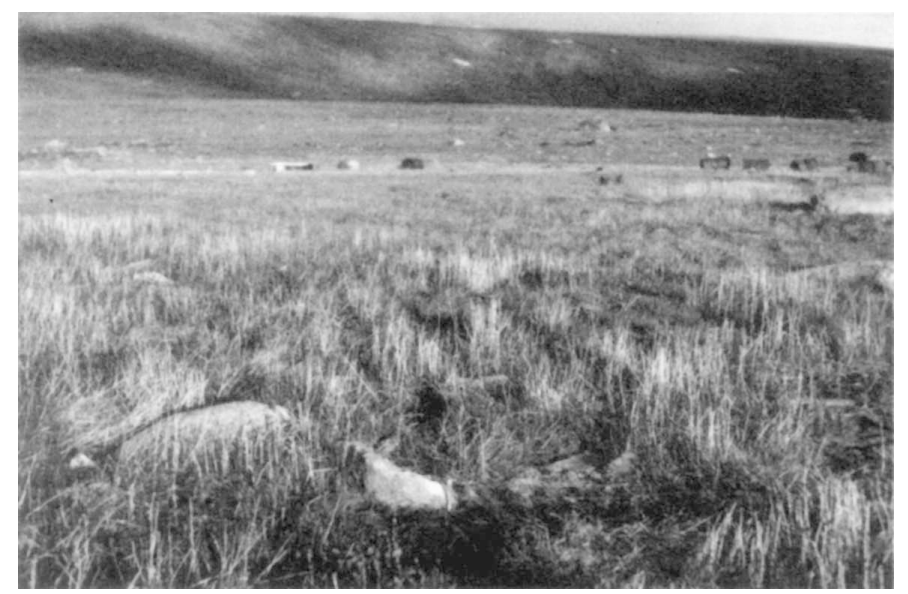

FIG. 3. General aspect of contemporary Inuit housepad at Clyde River, Baffin Island. This site has no sand or gravel added and was abandoned in 1969. This view shows the prominence of merging clones of Alopecurus alpinus on the housepad and on adjoining heavily trampled ground. Note the high density of inflorescences visible in the foreground. In the near background, Alopecurus becomes less prominent, and a dense turf on moderately trampled ground is instead dominated by Poa arctica. Scale is given by last year's dead standing culms of Alopecurus $(\approx 30 \mathrm{~cm})$. Photo date: 15 July 1988.

\section{METHODS}

Sampling methods followed Westhoff and van der Maarel (1978), with the following modifications: (1) vascular vegetation cover was estimated in the field to the nearest $1 \%$ and later transformed according to van der Maarel's (1979) 1-9 scale prior to multivariate analyses; (2) cover of nonvascular taxa was ranked in the field as few, abundant or dominant and later transformed to presence/absence prior to multivariate analyses. Thus, bryophytes and lichens can only achieve an abundance level of 1 in the ordinations. Detailed vegetation sampling methods for contemporary disturbances on Baffin Island and Devon Island and adjoining controls are described elsewhere (Forbes, 1992a,b). The four archaeological sites were sampled in a manner similar to the temporary Inuit housepads (ca. 1963-69) at Clyde River on Baffin Island. Five $30 \mathrm{~m}$ transects (quadrats placed every six meters) were randomly placed on each housepad, emanating from a rough pentagon in the center formed by the first five samples. This distance was chosen to encompass the complete gradient from the housepad across adjoining trampled ground. Samples comprising five randomly placed $25 \times 50 \mathrm{~cm}$ quadrats (Wein and Rencz, 1976) were situated on each dwelling, with quadrats restricted to the floors of the unexcavated dwellings and to the back wall of the reconstructed dwelling. Five controls were situated on the adjoining (1-2 m distant), relatively undisturbed crest of the beach ridge. The paucity of structurally intact fruticose lichens on the beaches indicated occasional visits by other people.

In each quadrat vascular vegetation was sampled for composition, frequency, and cover to the nearest $1.0 \%$. Presence/absence of nonvascular vegetation was sampled using a $10 \times 10 \mathrm{~cm}$ quadrat nested within each $25 \times 50 \mathrm{~cm}$ quadrat. Taxa occurring outside the $100 \mathrm{~cm}^{2}$ quadrats but within the $1250 \mathrm{~cm}^{2}$ quadrats were also recorded and included in the samples. Since biomass was being sampled simultaneously (Forbes, 1994), each quadrat was turned over and both vascular and nonvascular plants were counted again. Including controls, this resulted in a total of 20 quadrats for each Thule dwelling (10 on and 10 off) and 40 quadrats for each Inuit housepad and its adjoining meadows at Clyde River.

Soil sampling on Baffin and Devon Islands took place near the peak of the growing season after a week of no precipitation. Standard procedures were used for gravimetric measuring of water and determining bulk density, and $\mathrm{pH}$ (Sheldrick, 1984). The $\mathrm{pH}$ of mineral (and occasionally highly organic) soils was measured in the field for each quadrat, using a $\mathrm{pH}$ meter (Cole Parmer model 5985-80 Digi-Sense ${ }^{\mathrm{TM}}$ ) accurate to \pm 0.05 . Surface water $\mathrm{pH}$ was measured in disposable $50 \mathrm{ml}$ paper cups. Mineral soils were thoroughly mixed with distilled water at a ratio of 1:1 several times over a period of 30 minutes. The ratio of soil to water was adjusted to $1: 4$ for samples with high organic content. These slurries were then allowed to stand for 30 minutes at room temperature (approx. $15^{\circ} \mathrm{C}$ ), after which time readings were taken with the glass electrode in the supernatant water.

Soil moisture and bulk density were measured at a depth of between 10 and $15 \mathrm{~cm}$ using $100 \mathrm{cc}$ cores from each quadrat. After an initial 'wet' weighing, cores were air-dried at room temperature for two weeks, then oven-dried at $105^{\circ} \mathrm{C}$ for 24 hours and weighed again in the field with a triple-beam balance to the nearest $0.10 \pm 0.10 \mathrm{~g}$. Cores were then sieved 
and stone content was considered to comprise the fraction $>2 \mathrm{~mm}$ in diameter, thereby allowing correction for the weight of the stones in gravimetric water determination.

Synchronous soil temperatures from depths of 5, 10, and $15 \mathrm{~cm}$ in each quadrat were measured hourly during several 24-hour periods at Truelove Lowland. Data were chosen from one period (29-30 July 1990) considered representative of 'typical' conditions at this site-overcast skies with an ambient temperature of $3.8^{\circ} \mathrm{C}$ - on the basis of long-term summer climate records (J. Trask, pers. comm. 1991). Readings were made using YSI ${ }^{\mathrm{TM}}$ Series 4000 thermistors mounted with epoxy on fiberglass rods and inserted into pre-formed holes. Measurements accurate to $\pm 0.1^{\circ} \mathrm{C}$ were made upon equilibration, and the results from the different depths were pooled and averaged to obtain a summary value. Slope was measured using an Abney level.

The vegetation data were first classified numerically with the polythetic divisive two-way indicator species analysis TWINSPAN (Hill, 1979; Forbes, 1994). The same raw data sets were then ordinated using detrended correspondence analysis (DCA) in the program CANOCO (ter Braak, 1991). Because of the limited dimensions of the program regarding samples, the data were analyzed using the following data subsets: (1) undisturbed and disturbed stands were subjectively separated when analyzing all three study sites together; (2) both disturbed and undisturbed stands at Clyde River were analyzed together; (3) both disturbed and undisturbed stands at Truelove Lowland and Resolute Bay were analyzed together. Initial runs determined that rare taxa were unimportant in the classification of stands, and these were removed prior to subsequent analyses. Rare taxa were considered to be those occurring in only one sample in a given stand; most were erect solitary forbs, Equisetum spp., and lichens.

Canonical correspondence analysis (CCA) was subsequently used to explore vegetation-environment relationships with the program CANOCO (ter Braak, 1991). Environmental variables included in the analysis were soil moisture, soil bulk density, organic mat depth, substrate $\mathrm{pH}$, local slope, and soil temperature. These data were handled using the same succession of data subsets analyzed with DCA.

Preliminary analyses showed that the first axes of all ordination biplots were longer than 3.6 SD, with most being longer than 3.8 SD and some longer than 4.0 SD. On the basis of these results, it was decided to use DCA for species ordination and CCA for constrained ordination. Throughout the DCA analyses, the option for detrending by segments was used, as recommended by Økland (1990). In interpretation of the results presented, the emphasis is on sample ordinations. Van Groenewoud (1992) cautions against the temptation to pack too much into the analysis, and he recommends restricting sampling mainly to one gradient at a time.

In my CCAs I used the Scaling option 1 in CANOCO for CCA. Scaling 1 is more appropriate when the focus is on the configuration of samples in the ordination; with Scaling 1, the distance between samples approximates the chi-square distance (ter Braak, 1990). Computational details of CCA are provided by ter Braak (1987). In the ordination biplots, lines were drawn around the outside edge of the collective quadrat scores for each sample. This made it much easier to discern the boundaries between overlapping samples.

\section{RESULTS}

\section{Ordination of Thule Dwellings and Adjoining Beach Ridges at Truelove Lowland and Resolute Bay}

The DCA ordination of Thule dwellings and adjoining beach ridges (Fig. 4) reveals a strong primary gradient (eigenvalue $=0.640$ ) and an almost complete differentiation in species composition between the extremes (estimated gradient length $=3.824 ; \mathrm{A}$ in Table 1). The beach ridges of both Truelove Lowland and Resolute Bay are clustered together and are relatively similar. There is far more variation among the Thule dwellings, even among unexcavated dwellings at Truelove Lowland which are less than $15 \mathrm{~m}$ apart (T15on, T16on). Axis 1 corresponds to moisture, which increases from left to right in the diagram.

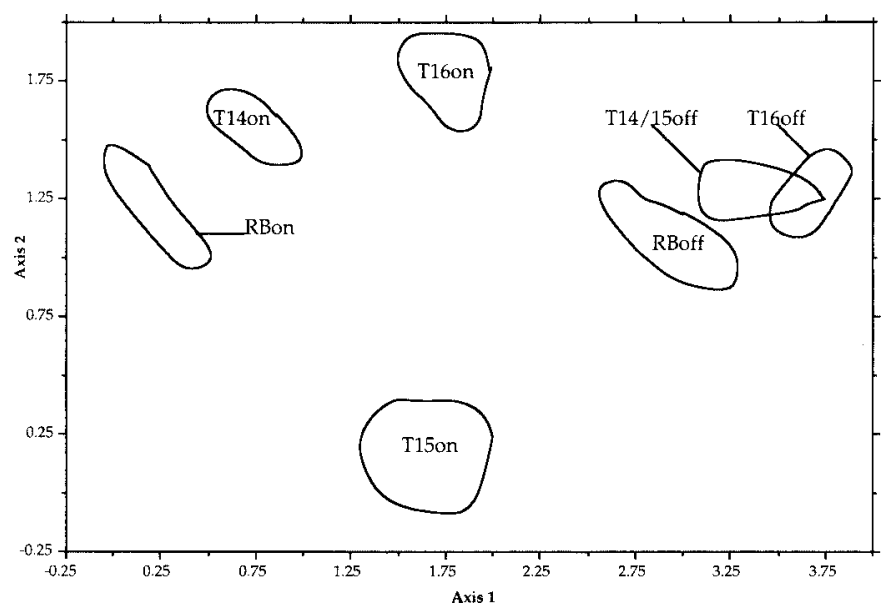

FIG. 4. Ordination (DCA, Scaling 1) biplot of Thule dwellings and adjoining beach ridges at Truelove Lowland and Resolute Bay. Sample stand designations for this and all other biplots are as follows: $\mathrm{T}=$ Truelove Lowland; $\mathrm{RB}=$ Resolute Bay; on $=$ Thule dwelling; off $=$ adjoining raised beach ridge. Stand T14on comprises the recently excavated Thule dwelling. All other dwellings are unexcavated. See A in Table 1 for summary of ordination statistics. See Table 2 for species $\times$ site summary.

The number of 'active' species in the analysis (77) is twice that in Truelove Lowland's hummocky sedge-moss meadows (Forbes, 1994), with many more ruderal plants (e.g., Alopecurus alpinus, Leptobryum pyriforme, etc.) figuring prominently on the dwellings. A complete list of species and their vegetation cover values appears in Table 2. Some vascular plants (e.g., Carex aquatilis var. stans, Juncus biglumis) are nearly omnipresent and occur at various frequencies on both beach ridges and dwellings. These contribute to the high species richness of the latter (Forbes, 1993). Salix arctica occurs in both of these vegetation types and in sedge-moss meadows as well and displays probably the 
TABLE 1. Ordination statistics for detrended correspondence analyses (DCA).

A. Thule dwellings and beach ridges at Truelove Lowland and Resolute Bay

\begin{tabular}{lcccc} 
& \multicolumn{4}{c}{ Axes } \\
\cline { 2 - 5 } & 0.640 & 0.239 & 0.108 & 0.059 \\
Eigenvalues & 3.824 & 1.899 & 1.838 & 1.472 \\
Length of gradient & & & & \\
$\begin{array}{l}\text { Cumulative percentage variance } \\
\quad \text { of species data }\end{array}$ & 24.7 & 33.9 & 38.1 & 40.3 \\
Sum of all unconstrained eigenvalues & & & & 2.593
\end{tabular}

B. Thule dwellings, housepads and trampled ground at Clyde River, Truelove Lowland and Resolute Bay

\begin{tabular}{lcccc} 
& \multicolumn{5}{c}{ Axes } \\
& 1 & 2 & 3 & 4 \\
\cline { 2 - 5 } & 0.528 & 0.405 & 0.234 & 0.143 \\
Eigenvalues & 4.051 & 3.503 & 3.398 & 2.308 \\
$\begin{array}{l}\text { Length of gradient } \\
\quad \text { of species data }\end{array}$ & 11.6 & 20.5 & 25.7 & 28.8 \\
$\begin{array}{l}\text { Sum of all unconstrained eigenvalues } \\
\text { nomy }\end{array}$ & & & & 4.547 \\
\hline
\end{tabular}

C. Thule dwellings, housepads and trampled ground at Clyde River, Truelove Lowland and Resolute Bay (with generic Poa and Stellaria spp.)

\begin{tabular}{|c|c|c|c|c|}
\hline & \multicolumn{4}{|c|}{ Axes } \\
\hline & 1 & 2 & 3 & 4 \\
\hline Eigenvalues & 0.518 & 0.354 & 0.199 & 0.130 \\
\hline Length of gradient & 3.999 & 3.026 & 2.859 & 2.403 \\
\hline $\begin{array}{l}\text { Cumulative percentage variance } \\
\text { of species data }\end{array}$ & 12.9 & 21.7 & 26.7 & 29.9 \\
\hline Sum of all unconstrained eigenvalues & & & & 4.016 \\
\hline
\end{tabular}

widest ecological amplitude of all species. The second axis is more poorly defined (eigenvalue $=0.239$ ) and shorter (estimated length $=1.899$ ), with much lower species turnover. Its endpoints appear to be based on the variations in relative soil moisture. Subtle differences in species composition differentiate the moist stand T15on from the only slightly more mesic stand T16on. Small amounts of Carex aquatilis var. stans, Arctagrostis latifolia ssp. latifolia, and Juncus biglumis occur only on the former, whereas the latter is characterized by a high frequency of the moss Drepanocladus uncinatus (Forbes, 1993).

Ordination of Thule Dwellings, Contemporary Housepads, and Adjoining Trampled Ground at Truelove Lowland, Clyde River and Resolute Bay

Ordination of the combined Thule dwellings, contemporary housepads, and pedestrian-trampled stands revealed strong local and geographic affinities among the vegetation cover types. The first axis was strongly linked with disturbance intensity (eigenvalue $=0.528$ ), increasing from left to right. The second axis (eigenvalue $=0.405$ ) was correlated with increasing moisture. Estimated gradient lengths for the first two axes were 4.051 and 3.503 , respectively, and species turnover was high in both cases (B in Table 1). The vegetation of the two unexcavated Thule dwellings from Truelove Lowland (stands T15on, T16on) was closest to the lightly and moderately trampled meadows from Clyde River (stands 18lgt, 18mod). Similarly, Stand 19on appeared on the far

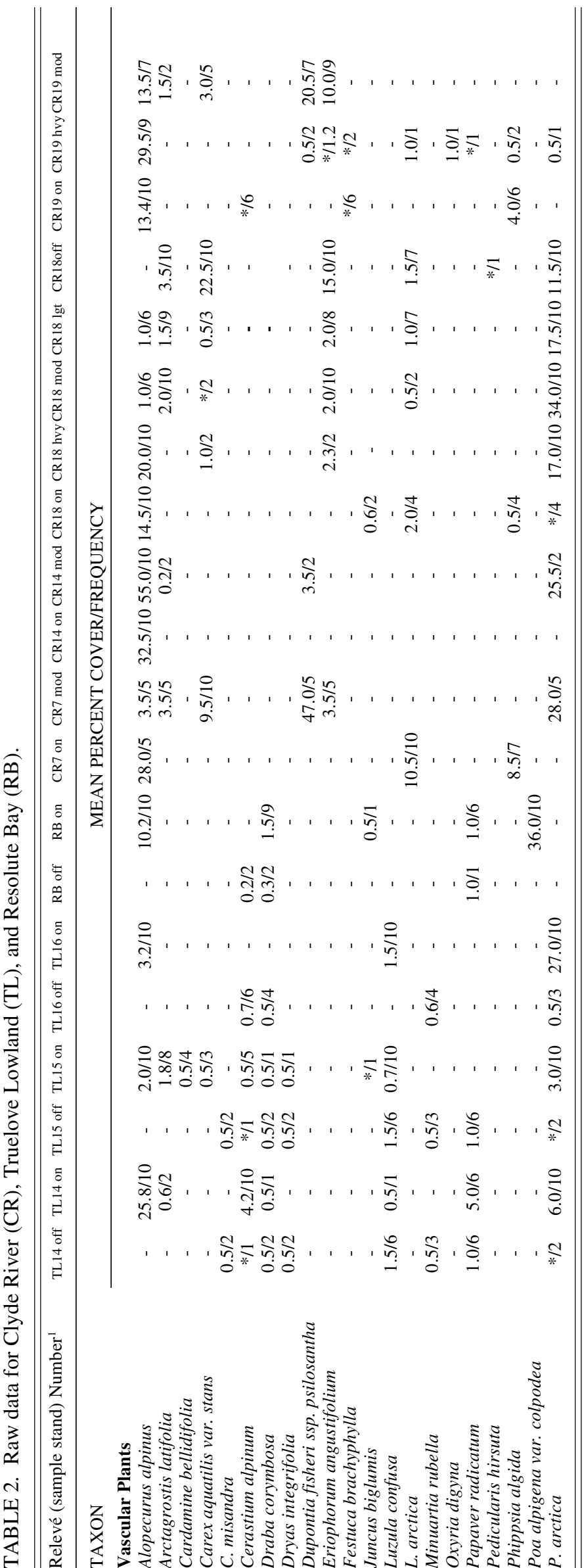




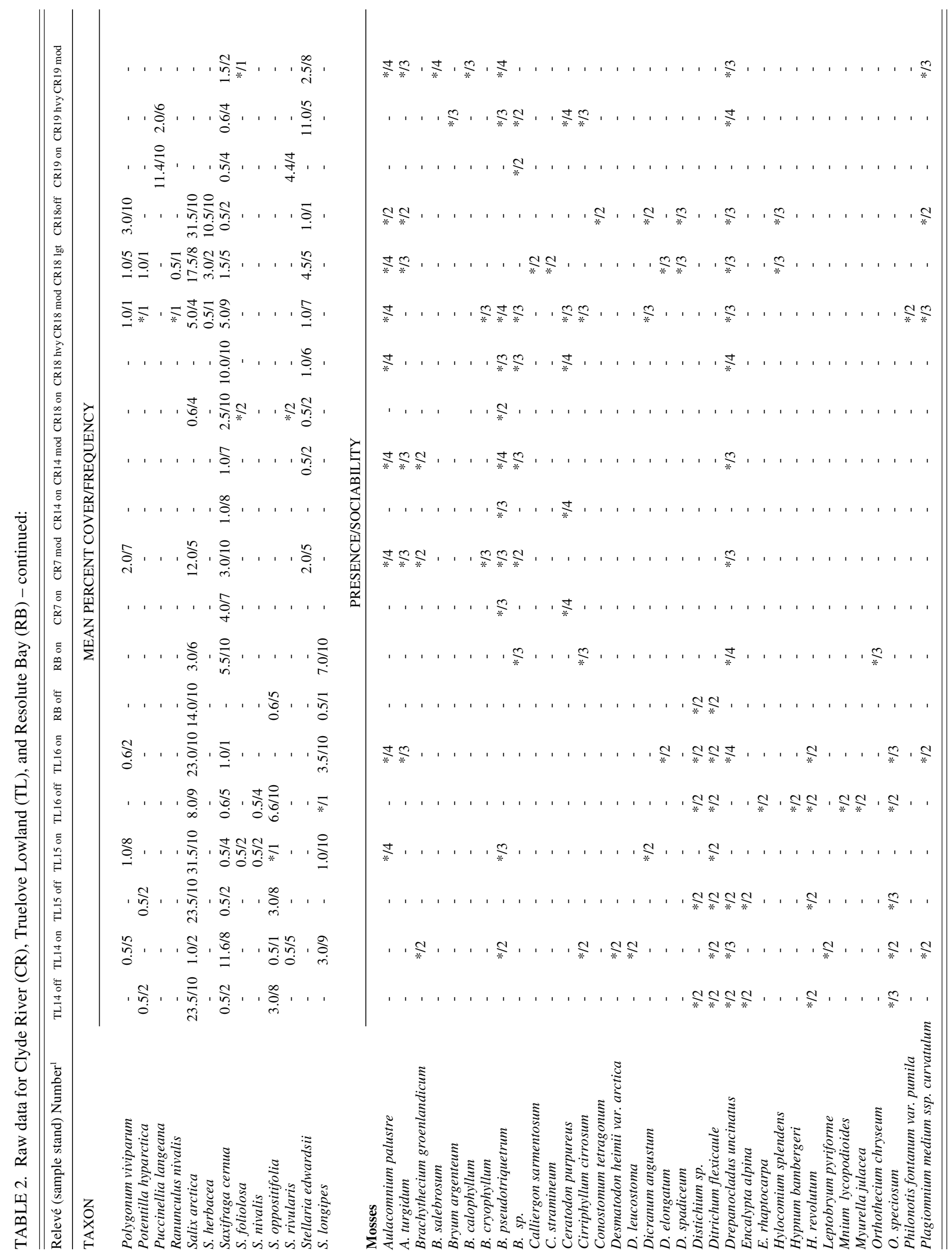




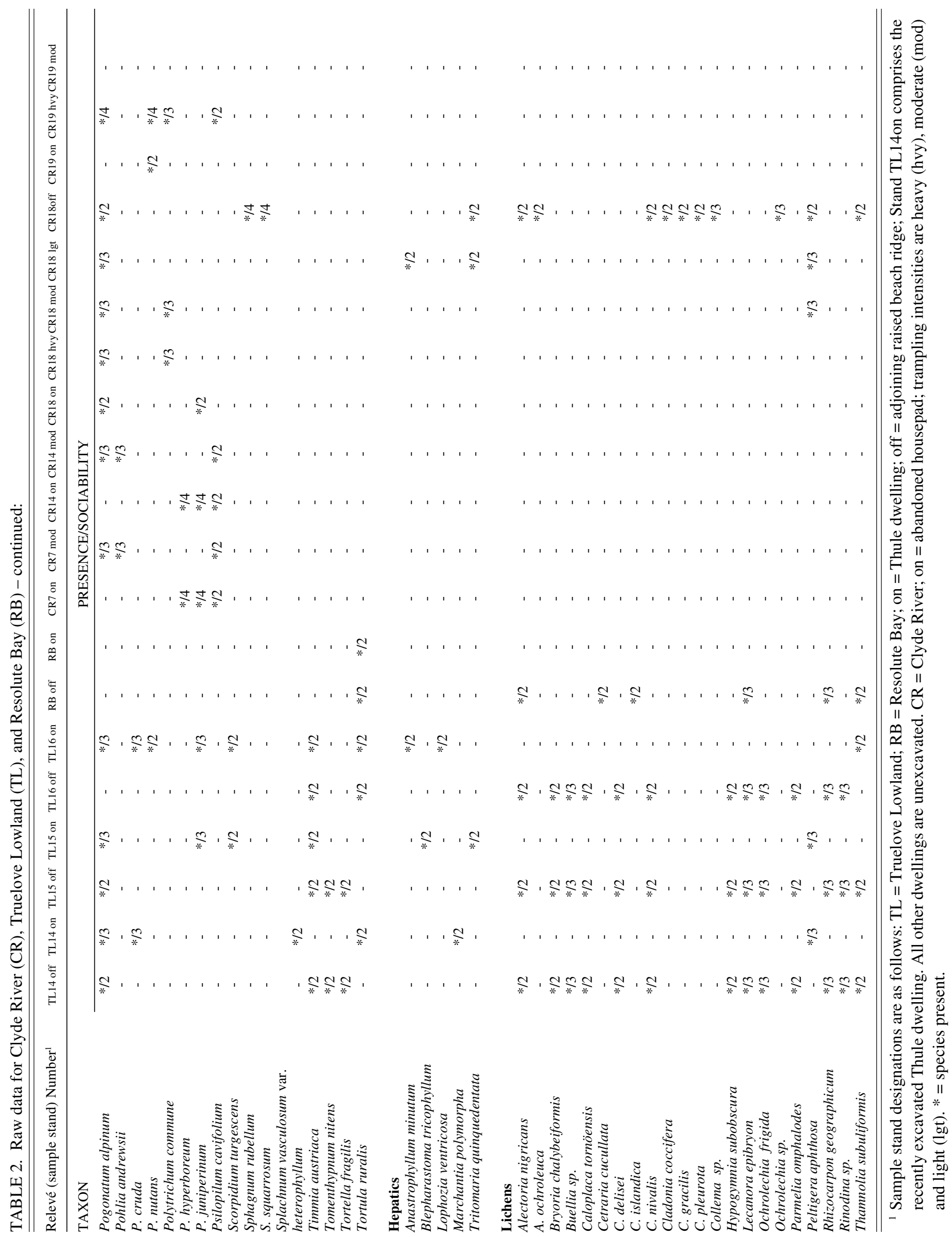


right (severely disturbed) end of the gradient, while Stand 18 lgt occupied the far left (relatively undisturbed) end. It is notable that the trampled portions of Stands 14, 19, and especially 7 , displayed relatively abundant cover of the grass Dupontia fisheri ssp. psilosantha (Table 2), a species characteristic of wetland habitats (Porsild and Cody, 1980). Stand 18 was more mesic by comparison, and on the moderately and heavily trampled portions the dominant grasses were A. alpinus and Poa arctica (Table 2). This helps to explain the relative differentiation among the trampled stands at Clyde River.

Four of the most abundant ruderal plants which differ among the three sites are paired congenerics with similar life histories: two rhizomatous viviparous grasses (P. arctica and $P$. alpigena var. colpodea) and two prostrate matted forbs (Stellaria longipes and S. edwardsii). If not for these differences, the geographic linkages among the plant communities would be even greater.

To verify this, the four plants were treated as two generics (Poa and Stellaria spp.) and the same data set was ordinated once again (Fig. 5). Indeed, species turnover along the second axis was reduced ( $\mathrm{C}$ in Table 1 ) and the positions of the Thule dwellings on Devon and Cornwallis Islands reflected a closer affinity to the moderately and heavily trampled mesic meadows on Baffin Island. These changes indicate that although close floristic relationships exist among these sites, the differences are further minimized if we concentrate on the growth forms present. The recently excavated dwelling (T14on) at Truelove Lowland moves to the lower periphery of the ordination space, reflecting the six mosses which occur in no other samples (i.e., Ceratodon purpureus; Table 2). Many of these same ruderal mosses (e.g., Bryum argenteum, Desmatodon heimii var. arctica, Tortula ruralis) were collected on the spoil heap a few meters away.

\section{Constrained Ordination of Thule Dwellings and Adjoining Beach Ridges at Truelove Lowland}

Before CCA was run for this data subset, data from the Thule dwelling and adjoining beach ridge samples from Resolute Bay were removed because environmental data were lacking for those stands. The eigenvalue for the first axis is decreased relative to the DCA, from 0.640 to 0.550 , while the value for the second axis remains almost unchanged (Table 3). The first axis is primarily one of moisture and $\mathrm{pH}$, both of which are negatively correlated with organic mat depth (Fig. 6, Table 4). In observing that relative moisture is highest on the beach ridges (Table 5), it should be noted that these values reflect the soil between the large cobbles which cover much of the surface. The substrate of the Thule dwellings, by comparison, was composed of peat, which was relatively dry when sampled late in the growing season.

The second axis has a moderate negative correlation with organic mat depth (coefficient $=-0.59$ ). Both the first axis and overall results were found to be significant at $p=0.01 \mathrm{using}$ the Monte Carlo permutation test included in CANOCO. All of the stands maintained significant distances from one another in both Scaling 1 (not shown) and Scaling 2, indicating

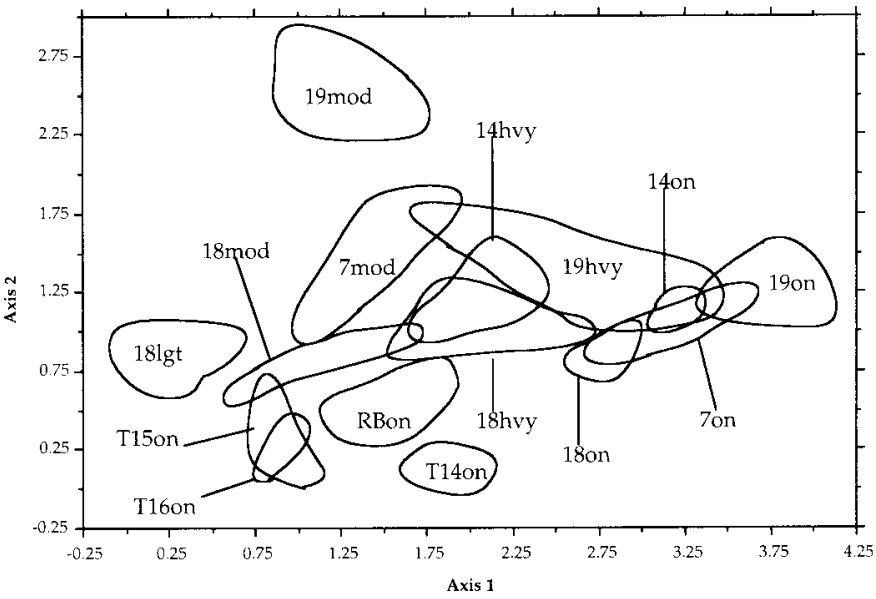

FIG. 5. Ordination (DCA, Scaling 1) biplot of Thule dwellings, contemporary housepads and adjoining trampled ground at Truelove Lowland, Clyde River and Resolute Bay with Poa and Stellaria spp. treated as generic species. Sample stand designations are as in Figure 4 with the following exceptions: samples with no letter prefix = Clyde River; stands 7, 14, 18 and 19 comprise abandoned housepads and adjoining trampled hummocky sedge-moss meadows at Clyde River; trampling intensities are heavy (hvy), moderate (mod) and light (lgt). See $\mathrm{C}$ in Table 1 for summary of ordination statistics.

TABLE 3. Eigenvalues and species-environment correlations from CCA of Thule dwellings and beach ridges at Truelove Lowland and Resolute Bay.

\begin{tabular}{|c|c|c|c|c|}
\hline & \multicolumn{4}{|c|}{ Axes } \\
\hline & 1 & 2 & 3 & 4 \\
\hline Eigenvalues & .550 & .234 & .185 & .119 \\
\hline Species-environment correlations & .962 & .840 & .807 & .810 \\
\hline Cumulative percentage variance & & & & \\
\hline of species data & 28.8 & 41.0 & 50.7 & 56.9 \\
\hline of species-environment relation & 49.1 & 69.9 & 86.4 & 97.1 \\
\hline
\end{tabular}

that both species and environment differ appreciably among stands. All individual environmental variables except organic mat depth and bulk density achieved $p$-values of 0.01 in the Monte Carlo test. It could therefore be concluded that the vegetation showed significant differences with respect to the environmental variables correlated with the axis.

\section{DISCUSSION}

At least three factors influence the contemporary vegetation cover at a given site of prehistoric human activity in the Arctic. First is the location of the initial and sustained impact. This is probably a nonrandom factor, since Thule peoples and modern Inuit made conscious decisions about camp location (Treude, 1977; Jacobs and Sabo, 1978; Jacobs, 1988). Ideal sites or 'resource patches' were chosen on the basis of combinations of mesoclimate, access to wildlife, and local plant resources. Many prehistoric camps were located in protected coastal sites with well-drained beach ridges or cobble for situating tents and other dwellings. Inland camps were also not uncommon, and appear to have been more common during periods of ameliorated climatic conditions 


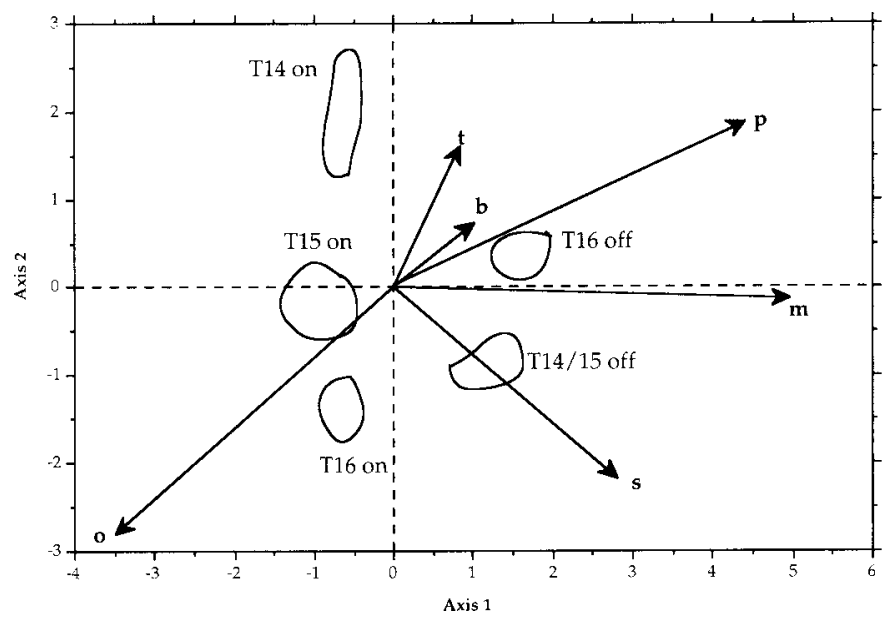

FIG. 6. Constrained ordination (CCA, Scaling 1) triplot of Thule dwellings and adjoining beach ridges at Truelove Lowland. Arrows indicating environmental variables are designated as follows; $\mathrm{b}=$ soil bulk density; $\mathrm{m}=$ soil moisture; $\mathrm{o}$ $=$ organic mat depth; $\mathrm{p}=$ substrate $\mathrm{pH} ; \mathrm{s}=$ local slope and $\mathrm{t}=$ soil temperature. See Table 4 for summary of ordination statistics. See Table 5 for summary of environmental parameters $\times$ sites

TABLE 4. Canonical coefficients and inter-set correlations for environmental variables used in CCA of Thule dwellings and beach ridges at Truelove Lowland and Resolute Bay.

\begin{tabular}{lrrrrr}
\hline \hline \multirow{2}{*}{ Parameter } & \multicolumn{2}{c}{ Canonical Coefficients } & & \multicolumn{2}{c}{ Inter-set Correlations } \\
\cline { 2 - 3 } \cline { 5 - 6 } & Axis 1 & Axis 2 & & Axis 1 & Axis 2 \\
\hline Organic Mat Depth & -0.676 & -0.590 & & -0.651 & -0.496 \\
Soil Moisture & 0.955 & -0.024 & & 0.919 & -0.021 \\
Soil pH & 0.849 & 0.345 & & 0.817 & 0.306 \\
Bulk Density & 0.190 & 0.143 & & 0.183 & 0.120 \\
Soil Temperature & 0.161 & 0.310 & & 0.155 & 0.260 \\
Slope & 0.543 & -0.421 & & 0.522 & -0.354 \\
\hline \hline
\end{tabular}

TABLE 5. Pooled means $(n=\geq 5)$ for environmental parameters ${ }^{1}$ at Clyde River, Baffin Island and Truelove Lowland, Devon Island.

\begin{tabular}{lrrrrrr}
\hline \hline \multicolumn{1}{c}{ BD } & SM & OM & pH & LS & ST \\
\hline Clyde River & & & & & & \\
7mod & 1.55 & 27.2 & 3.0 & 4.9 & $2^{\circ}$ & $6.8^{\circ}$ \\
7on & 1.68 & 9.8 & 0 & 5.6 & $0^{\circ}$ & $10.8^{\circ}$ \\
14hvy & 1.48 & 26.1 & 2.5 & 4.8 & $2^{\circ}$ & $6.8^{\circ}$ \\
14on & 1.63 & 17.2 & 0 & 5.6 & $0^{\circ}$ & $10.8^{\circ}$ \\
181gt & 1.58 & 17.7 & 4.3 & 5.3 & $2.5^{\circ}$ & $6.7^{\circ}$ \\
18mod & 1.41 & 25.8 & 6 & 5.2 & $2.5^{\circ}$ & $6.4^{\circ}$ \\
18hvy & 1.71 & 16.0 & 5.5 & 5.2 & $2.5^{\circ}$ & $7.6^{\circ}$ \\
18on & 1.86 & 12.9 & 0 & 5.1 & $0^{\circ}$ & $10.6^{\circ}$ \\
19mod & 1.17 & 40.5 & 9.5 & 4.8 & $1^{\circ}$ & $5.0^{\circ}$ \\
19hvy & 1.20 & 36.6 & 5 & 4.7 & $1^{\circ}$ & $7.4^{\circ}$ \\
19on & 1.29 & 17.7 & 0 & 5.2 & $0^{\circ}$ & $10.2^{\circ}$ \\
Truelove Lowland & & & & & \\
T14off & 0.34 & 86.8 & 2 & 7.2 & $3^{\circ}$ & $4.8^{\circ}$ \\
T14on & 0.31 & 66.5 & 3 & 6.7 & $0^{\circ}$ & $6.3^{\circ}$ \\
T15off & 0.34 & 86.8 & 2 & 7.2 & $2^{\circ} .5^{\circ}$ & $4.8^{\circ}$ \\
T15on & 0.31 & 66.9 & 4.5 & 6.4 & $0^{\circ}$ & $4.7^{\circ}$ \\
T16off & 0.33 & 85.7 & 1 & 7.1 & $0^{\circ}$ & $6.4^{\circ}$ \\
T16on & 0.27 & 61.1 & 6 & 6.0 & $0^{\circ}$ & $7.2^{\circ}$ \\
\hline \hline
\end{tabular}

${ }^{1}$ Abbreviations are as follows: soil bulk density (BD) as \%; gravimetric soil moisture (SM); organic mat depth (OM) in cm; substrate $\mathrm{pH}(\mathrm{pH})$; local slope (LS); and soil temperature (ST) in ${ }^{\circ} \mathrm{C}$. on southern Baffin Island (Jacobs, 1988). There, meadows and heaths provided habitat for grazing animals, as well as a source of human plant foods (e.g., Empetrum nigrum ssp. hermaphroditum, Vaccinium uliginosum) and fuels (e.g., Cassiope tetragona).

A second suite of factors comprises the type, frequency, size, shape, and intensity or magnitude of the initial disturbance (van Andel and van den Bergh, 1987; Petraitis et al., 1989). For example, among contemporary disturbances it has been demonstrated that denuded narrow strips (e.g., vehicle tracks) naturally revegetate more quickly than large bare patches (e.g., housepads), especially when sand or gravel is added (Forbes, 1993). A third factor is the available flora, as determined by camp location, but subject to local and regional limitations which vary largely according to climatic, edaphic, and hydrological parameters (Steere, 1953; Edlund, 1990; Bliss and Matveyeva, 1992). Within the directly affected and proximal flora, species' life histories are key factors in determining the nature of the short- and long-term response and whether or not recovering plant communities resemble those originally displaced. The number and type of growth forms present appear to be of particular importance (Forbes, 1992a,b).

For example, an important clonal graminoid in this study was Alopecurus alpinus, a species absent from all of the 'undisturbed' meadows sampled (Forbes, 1994), but frequent, even dominant, on Thule dwellings and contemporary housepads and trampled meadows. Alopecurus is common on zoogenic and cryogenic disturbances, such as bird cliffs, animal burrows, and the active margins of ice-wedge polygons, and has long been associated with arctic archaeological sites (Porsild, 1932; Polunin, 1948; Fredskild, 1961). Alopecurus was much less prominent on Thule winter dwellings surveyed by McCartney (1979) at Silumiut, where Poa spp. were dominant among graminoids.

Even if the maturing of seed in this species is a rare event (Nosko, 1984; L.C. Bliss, pers. comm. 1991), the persistence of viable graminoid seed in the seed bank (see McGraw et al., 1992) would help to explain the abundance of seedlings of Alopecurus, Arctagrostis latifolia ssp. latifolia and Poa arctica ssp. arctica and the rapid dominance of these and several other species on the recently excavated Thule dwelling (Fig. 2), and the adjacent spoil heap at Truelove Lowland. The latter, which was sampled for flora but not vegetation (Table 6), was located on a nearby rock outcrop about $1.5 \mathrm{~m}$ above the beach. Within three years, the entire patch of several square meters was covered with robust individuals of Saxifraga cernua and Polygonum viviparum. Only S. cernua occurred on the nearby beach ridge. Both species reproduce from rather heavy vegetative corms, bulblets, and bulbils. Such propagules probably remain viable for only one year (G.H.R. Henry, pers. comm. 1993) and they are unlikely to have dispersed up to the ledge in large numbers in such a short time. Studies of aeolian propagule transport at Truelove Lowland (Teeri and Barrett, 1975) and elsewhere (Grulke and Bliss, 1983) have reported mostly moss or lichen fragments and grass seeds in snow cores. 
TABLE 6. Floristics of natural and anthropogenic disturbances in the eastern Canadian Arctic.

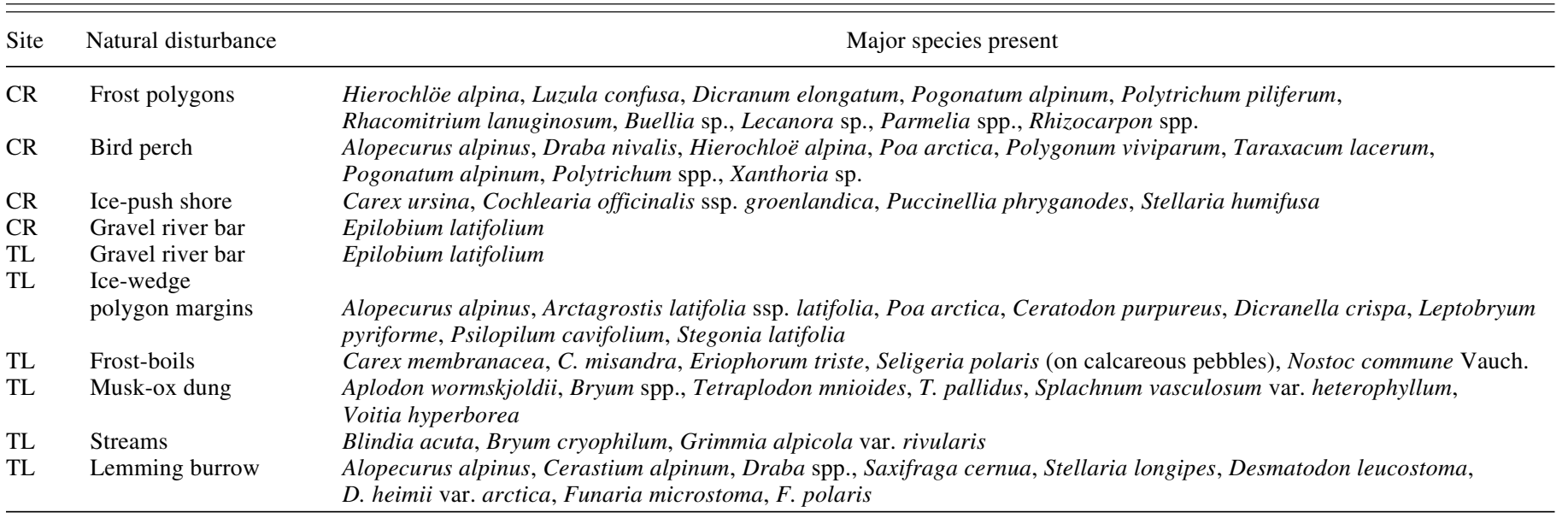

Anthropogenic habitats for which floras were sampled but no formal measurements were made.

$\begin{array}{cl}\text { EF } & \begin{array}{l}\text { Abandoned } \\ \text { sod/stone houses } \\ \text { Abandoned } \\ \text { sod/stone houses } \\ \text { Abandoned } \\ \text { PI }\end{array} \\ \text { RBd/stone houses } \\ \text { CR } & \begin{array}{l}\text { Effluent spillway } \\ \text { Roadside } \\ \text { Spoil heap from } \\ \text { archaeological dig }\end{array} \\ \text { CR }\end{array}$

Alopecurus alpinus, Papaver radicatum, Poa arctica, several others

Alopecurus alpinus, Matricaria ambigua, several others

Alopecurus alpinus, Cerastium alpinum, Chrysoplenium tetrandum, Draba alpina, Juncus biglumis, Luzula nivalis, Minuartia rubella, Oxyria digyna, Poa spp., Polygonum viviparum, Puccinellia spp. Alopecurus alpinus, Arctagrostis latifolia ssp. latifolia, Oxyria digyna, Ranunculus pygmaeus Epilobium latifolium

Alopecurus alpinus, Cerastium alpinum, Festuca brachypyhlla, Papaver radicatum, Poa arctica, Polygonum viviparum, Saxifraga cernua, S. rivularis, Stellaria longipes, Melandrium apetalum ssp. apetalum, Brachythecium collinum var. subjulaceum, Bryum argenteum, Desmatodon heimii var. arctica, Dicranum elongatum, Plagiomnium ellipticum, Rhacomitrium lanuginosum, Tortula ruralis

$\mathrm{CR}=$ Clyde River, Baffin Island, EF = Eglinton Fiord, Baffin Island, PI = Pond Inlet, Baffin Island, RB = Resolute Bay, Cornwallis Island, $\mathrm{TL}=$ Truelove Lowland, Devon Island. Sources include my own personal collections in addition to reports by Polunin (1948), Schofield and Cody (1955), Vitt (1975), Vitt and Pakarinen (1977), and Nosko (1984).

Other abundant plants on the spoil heap, such as Papaver radicatum, Cerastium alpinum, Stellaria edwardsii and $S$. longipes, produce lighter and regularly viable seeds, but it seems unlikely that they would have so thoroughly colonized the site in such a short time. Such an interpretation would indicate recruitment from a rich, viable seed bank present in the highly organic soils of the Thule dwelling at the time of excavation. An alternative explanation is that establishment of a few individuals of these species on the organic- and nutrient-rich substrate could have provided large numbers of viable seeds and healthy individuals over the three years since disturbance. This highlights a key difference between the study sites: whereas the Thule dwellings and excavation spoil heaps comprise substantial amounts of intentional and highly concentrated organic deposition (peat, bone, blubber, etc.), the contemporary housepads and adjoining trampled meadows are solely the result of mechanical disturbance (i.e., compaction). Before Clyde River was abandoned, animal wastes were minimal and both they and human wastes were, by and large, deposited well away from the Inuit residences.

Stands T14on and RBon represent recently excavated and unexcavated dwellings at Truelove Lowland and Resolute Bay, respectively. In a classification analysis of this data set
(Forbes, 1994), these stands were differentiated from the previous group of moderately trampled meadows by the presence of Tortula ruralis. T. ruralis is characterized by Vitt (1975) as widespread at Truelove Lowland, most frequent in crevices and at the bases of calcareous rocks, but also common in drier meadows and often associated with Ditrichum flexicaule. Brassard (1971) reported T. ruralis to be one of the most conspicuous species around the ruins of Fort Conger on northern Ellesmere Island. More important than the differentiation based on $T$. ruralis is the large number of shared components from these sites, notably a moderately to very dense turf that comprised viviparous and rhizomatous graminoids, such as Poa spp. and Alopecurus alpinus.

The understory vegetation of the Thule dwellings comprised mats of the mosses Aulacomnium palustre and Drepanocladus uncinatus, with abundant Cirriphyllum cirrosum and basal rosettes of the forb Saxifraga cernua. Another notable aspect of the vegetation of these stands was the foliose lichen Peltigera aphthosa. This lichen was lacking on the beach ridges at Truelove Lowland and Resolute Bay but had colonized the recently excavated dwelling (stand T14on), where it was abundant between the flagstones of the central floor. $P$. aphthosa also occurred in the moderately trampled portion of a mesic meadow at Clyde River, where it 
had greater frequency and cover on the tops and sides of trampled hummocks than on nearby undisturbed hummocks. At Creswell Bay, Somerset Island $\left(72^{\circ} 47^{\prime} \mathrm{N}, 93^{\circ} 47^{\prime} \mathrm{W}\right)$, McCartney (1978) reported the growth of $P$. aphthosa to be 'luxuriant' on the middens of Thule winter dwellings. On the excavated dwelling, several species of ruderal mosses were recorded which occurred in none of the other samples (Table 2). Yet many of these same mosses were collected on the spoil heap a few meters away and are reported for both anthropogenic and zoogenic patches at Silumiut, Northwest Territories $\left(63^{\circ} 41^{\prime} \mathrm{N}, 90^{\circ} 05^{\prime} \mathrm{W}\right)$ (McCartney and Crum, 1974). For comparative purposes, Table 6 presents species lists from various anthropogenic and natural disturbances in the eastern Canadian Arctic.

We lack comprehensive data on the contemporary plant communities of truly arctic archaeological sites. However, Fredskild (1961) made intensive phytosociological investigations of the former Native settlement of Sermermiut $\left(69^{\circ} 10^{\prime} \mathrm{N}, 51^{\circ} 08^{\prime} \mathrm{W}\right)$ in western Greenland. He reported Alopecurus alpinus and Poa arctica as codominant vascular species on the walls and floors of old dwellings. The third most prominent vascular plant present was Stellaria longipes. As with both modern and ancient sites in the present study, the prominent mosses were Aulacomnium spp., Drepanocladus uncinatus, and Tortula ruralis. The graminoid swards that occupied the Greenlandic dwellings appear floristically similar to the swards described for the Thule camp at Silumiut by McCartney (1979), although she generally reports much lower cover values for Alopecurus.

A number of retrospective studies provide strong evidence that synanthropic floras, faunas, and enriched soils have long been associated with prehistoric and historic settlements in the circumpolar North (Lutz, 1951; van der Knapp, 1985; Fredskild, 1988; Moore and Denton, 1988; Zutter, 1992; Böcher and Fredskild, 1993). Although the soil fauna was not investigated for sites in the present study, a recent report of mechanical anthropogenic disturbance on northern Ellesmere Island reveals significant variations in the composition and reproductive mode of arthropod populations at the scale of the patch (Kevan et al., 1995). These differences had persisted for some 13 years after the cessation of human activity. The implication is that the effects, both above and below ground, of highly local human activity may be detected long after the departure of humans.

The anthropogenic plant communities of 'Old' Clyde River have existed entirely within the known modern climatic regime for this site (Maxwell, 1981; Edlund, 1990). In contrast, the plant cover of the Thule dwellings at Truelove Lowland and Resolute Bay may have persisted in more or less similar form for centuries. Regardless, the macroclimatic regime has certainly undergone substantial change since the human occupancy of these sites (Svoboda, 1982). In light of these aggregate differences, the spatial and temporal floristic linkages among the sites indicate that the High Arctic exhibits an extremely limited range of responses to anthropogenic surface disturbance. These linkages may persist for decades, or even centuries.
The reasons for the persistence of these communities is not clear. However, it is well known from studies in temperate regions that invasion into dense, graminoid-dominated swards by species both within and outside the existing community is restricted by several factors. Many studies point to the absence of regeneration niches (sensu Grubb, 1977). In closed canopies with substantial litter layers, seedlings often fail to germinate or fare poorly after germination (Reader, 1991; Ryser, 1993). Once established, grasses can also benefit from repeated grazing by vertebrate herbivores, which appeared to have occurred at each of the study sites (Forbes, 1993). Intense soil compaction may be another factor. The bryogeographic linkages among the communities may last regardless of strong variations in local geology and bryophyte floristics.

\section{CONCLUSIONS}

In the present study, multivariate ordinations based on complete site floristics link the plant assemblages of Thuleera dwellings to those of modern human settlements some $750 \mathrm{~km}$ distant. Because the three sites lie on coastal lowlands within Edlund's (1990) $4^{\circ} \mathrm{C}$ bioclimatic zone, the naturally occurring vegetation types are characterized by largely similar vascular floras. Yet, differing lithologies cause the bryophyte floras which characterize these same communities to be quite different. Within a given landscape, even lowintensity human impact overrides local edaphic controls. The floristics, if not the vegetation, of anthropogenic patches are often quite similar. This may be true of patches of strikingly different origins and ages.

Data from sites of similar and differing origin and age provide clues to the extent of spatial and temporal patterns of establishment and persistence of anthropogenic plant communities. I am unaware of any previously published quantitative analyses of the plant cover of anthropogenically disturbed ground in the High Arctic that employ complete floristics. There appears to be a geography of responses to human impact within the context of floristics: the ruderal vascular floras of low arctic and subarctic prehistoric sites tend to be much richer than those of high arctic sites, particularly in truly maritime regions, and may include exotic species of temperate North American or European provenance (Porsild, 1932; Hrdlicka, 1937; Walker, 1946; Bank, 1953; Böcher and Lægaard, 1962; Pedersen, 1972).

Overall, the plant communities on anthropogenic disturbances reported here are clearly related in terms of their species composition, cover, and frequency. The anthropogenic patches were of strikingly different age, origin and environmental context. Specifically, these differences are as follows: (1) the Thule dwellings appear not to have been occupied by humans for centuries, versus $\leq 21$ years for the modern Inuit housepads and trampled sites; (2) the original disturbance regimes were different (repeated organic loading vs. repeated mechanical disturbance); and (3) the adjoining natural communities differ greatly (beach ridge vs. sedge-moss meadows). In spite of the wide separation in space, time, and environmental context 
of these anthropogenic patches, their contemporary floristics and vegetation are remarkably similar. This implies that an extremely limited number of growth forms within the arctic flora are able to colonize disturbed areas and that such patches so colonized may persist indefinitely.

\section{ACKNOWLEDGEMENTS}

I am grateful to C.D. Arnold of the Prince of Wales Northern Heritage Centre for granting permission to survey the Thule sites on Devon and Cornwallis Islands. I appreciated the input of J.W. Helmer, R.W. Park, and DIRS Camp Manager J. Trask and the field assistance of C.C. Earnshaw, H. Whitaker, and the late Jopi Tassugat. The Hamlet Council and people of Clyde River enthusiastically supported the work at the abandoned settlement (akiani) on Baffin Island. Funding and/or logistical support for this project were provided by the Arctic Institute of North America, the Department of Indian and Northern Affairs, the Social Sciences and Humanities Research Committee of McGill University, the Northern Heritage Society/Science Institute of the Northwest Territories, the Polar Continental Shelf Project, and G.W. Wenzel. Plant verifications, including many identifications, were made by I.M. Brodo, W.J. Cody, H.A. Crum, D.H. Vitt, and P.-Y. Wong. I thank G.H.R. Henry, N.G. McCartney, G.W. Wenzel, and the anonymous reviewers for valuable comments on earlier versions of the manuscript.

\section{REFERENCES}

ARKAY, K.E. 1972. Species distribution and biomass characteristics of the terrestrial vascular flora, Resolute Bay, N.W.T. M.Sc. thesis, McGill University, Montreal. $146 \mathrm{p}$.

BABB, T.A., and BLISS, L.C. 1974. Effects of physical disturbance on high arctic vegetation in the Queen Elizabeth Islands. Journal of Applied Ecology 11:549-562.

BANFIELD, A.W.F. 1975. Are arctic ecosystems really fragile? In: Luick, J.R., Lent, P.C., Klein, D.R., and White, R.G., eds. Proceedings of the First International Reindeer-Caribou Symposium. Fairbanks: Institute of Arctic Biology, University of Alaska. 546-551.

BANK, T.P., II. 1953. Ecology of prehistoric Aleutian village sites. Ecology 34:246-264.

BATES, G.H. 1938. Life forms of pasture plants in relation to treading. Journal of Ecology 26:452-454.

BLISS, L.C., and MATVEYEVA, N.V. 1992. Circumpolar arctic vegetation. In: Chapin, F.S., III, Jefferies, R.L., Reynolds, J.F., Shaver, G.R., and Svoboda, J., eds. Arctic ecosystems in a changing climate: An ecophysiological perspective. New York: Academic Press. 59-89.

BÖCHER, J., and FREDSKILD, B. 1993. Plant and arthropod remains from the palaeo-Eskimo site on Qeqertasussuk, West Greenland. Meddelelser om Grønland, Geoscience 30. 35 p.

BÖCHER, T.W., and LÆGAARD, S. 1962. Botanical studies along the Arfersiorfik Fjord, West Greenland. Botanisk Tidsskrift 58:168-190.
BRASSARD, G.R. 1971. The mosses of northern Ellesmere Island, Arctic Canada. II. Annotated list of the taxa. Bryologist 74:282 311.

BROOKS, R.R., and JOHANNES, D. 1990. Phytoarchaeology. Portland, Oregon: Dioscorides Press. 224 p.

DUNBAR, M.J. 1973. Stability and fragility in arctic ecosystems. Arctic 26(2):179-185.

ECKHARDT, F.E. 1988. Fragility of the plant cover in the Arctic. Flora 180:7-17.

EDLUND, S.A. 1990. Bioclimatic zones in the Canadian Arctic Archipelago. In: Harington, C.R., ed. Canada's missing dimension: Science and history in the Canadian Arctic Islands, Vol. 1. Ottawa: Canadian Museum of Nature. 421-441.

ELLENBERG, H. 1988. Vegetation ecology of central Europe, 4th ed. New York: Cambridge University Press. 731 p.

FORBES, B.C. 1992a. Tundra disturbance studies. I. Long-term effects of vehicles on species richness and biomass. Environmental Conservation 19:48-58.

_ 1992b. Tundra disturbance studies. II. Plant growth forms of human-disturbed ground in the Canadian Far North. Musk-ox 39:164-173.

1993. Anthropogenic tundra disturbance and patterns of response in the eastern Canadian Arctic. Ph.D. dissertation, McGill University, Montreal. 475 p.

1994. The importance of bryophytes in the classification of human-disturbed high arctic vegetation. Journal of Vegetation Science 5:877-884.

FREDSKILD, B. 1961. Floristic and ecological studies near Jakobshavn, West Greenland. Meddelelser om Grønland 163(4). 82 p. 1988. Agriculture in a marginal area: South Greenland from the Norse Landnam (985 A.D.) to the present (1985 A.D.). In: Birks, H.H., Birks, H.J.B., Kaland, P.E., and Moe, D., eds. The cultural landscape: Past, present and future. New York: Cambridge University Press. 381-393.

FRENKEL, R.E. 1972. Trampled vegetation and floristic convergence in the tropics. Association of Pacific Coast Geographers Yearbook 34:87-98.

GRUBB, P.J. 1977. The maintenance of species-richness in plant communities: The importance of the regeneration niche. Biological Review 52:107-145.

GRULKE, N.E., and BLISS, L.C. 1983. A note on winter seed rain in the High Arctic. Arctic and Alpine Research 15:261-265.

HARP, E., Jr. 1974. Threshold indicators of culture in airphoto archaeology: A case study in the Arctic. In: Vogt, E.Z., ed. Aerial photography in anthropological field research. Cambridge: Harvard University Press. 14-27.

HELMER, J.W. 1991. The palaeo-Eskimo history of the North Devon Lowlands. Arctic 44(4):301-317.

HILL, M.O. 1979. TWINSPANTM: a FORTRAN program for arranging multivariate data in an ordered two-way table by classification of the individuals and attributes. Ithaca, N.Y.: Department of Ecology and Systematics, Cornell University.

HRDLICKA, A. 1937. Man and plants in Alaska. Science 86:559 560.

HULTÉN, E., and FRIES, M. 1986. Atlas of north European vascular plants north of the tropic of Cancer. Köenigstein: Koeltz Scientific Books. 1171 p. 
IVES, J.D. 1970. Arctic tundra: How fragile? A geomorphologist's point of view. Transactions of the Royal Society of Canada 7:39-42.

JACOBS, J.D. 1988. Climate, vegetation and resources in southern Baffin Island. Occasional Papers of the Prince of Wales Northern Heritage Centre 3:75-91.

JACOBS, J.D., and SABO, G., III. 1978. Environments and adaptations of the Thule culture on the Davis Strait coast of Baffin Island. Arctic and Alpine Research 10:595-615.

KEVAN, P.G. 1971. Vehicle tracks on high arctic tundra: An 11 year case history around Hazen Camp, Ellesmere Island, N.W.T., Hazen 41. Ottawa: Defence Research Board. 17 p.

KEVAN, P.G., FORBES, B.C., BEHAN-PELLETIER, V., and KEVAN, S. 1995. Vehicle tracks on high arctic tundra: Their effects on the soil, vegetation and soil arthropods. Journal of Applied Ecology 32:656-669.

LUTZ, H.J. 1951. The concentration of certain chemical elements in the soils of Alaskan archaeological sites. American Journal of Science 249:925-928.

MAXWELL, J.B. 1981. Climatic regions of the Canadian Arctic Islands. Arctic 34(3):222-240.

McCARTNEY, N.G. 1978. Lichens from three archaeological sites, Somerset Island, N.W.T., Canada. Bryologist 81:610-613.

. 1979. Effects of Thule Eskimos on soils and vegetation at Silumiut, N.W.T. In: McCartney, A.P., ed. Thule Eskimo culture: An anthropological perspective. Archaeological Survey of Canada, National Museum of Man Mercury Series, Paper 88. Ottawa: National Museum of Canada. 495-527.

McCARTNEY, N.G., and CRUM, H.A. 1974. Some bryophytes of Silumiut Island, N.W.T. Canadian Field-Naturalist 88:361362.

McGRAW, J.B., VAVRECK, M.C., and BENNINGTON, C.C. 1991. Ecological genetic variation in seed banks. I. Establishment of a time transect. Journal of Ecology 79:617-625.

MONTI, P.W., and MACKINTOSH, E.E. 1979. Effect of camping on surface soil properties in the boreal forest region of northwestern Ontario, Canada. Soil Science Society of America Journal 43:1024-1029.

MOORE, T.R., and DENTON, D. 1988. The role of soils in the interpretation of archaeological sites in Northern Quebec. In: Bintliff, J., Davidson, D.A., and Grant, E.G., eds. Conceptual issues in environmental archaeology. Edinburgh: Edinburgh University Press. 25-37.

NOSKO, P. 1984. A comparative study of plant adaptations of Alopecurus alpinus in the Canadian High Arctic. Ph.D. dissertation, University of Alberta, Edmonton. 311 p.

ØKLAND, R.H. 1990. Vegetation ecology: Theory, methods and application with reference to Fennoscandia. Sommerfeltia (Suppl.) 1:1-233.

PARK, R.W. 1986. Report on the Northern Heritage Research Project's excavation at Truelove Lowland, Devon Island, NWT, 1986. Yellowknife: Northern Heritage Society. 26 p.

PEDERSEN, A. 1972. Adventitious plants and cultivated plants in Greenland. Meddelelser om Grønland 178(7). 99 p.

PETRAITIS, P.S., LATHAM, R.E., and NIESENBAUM, R.A. 1989. The maintenance of species diversity by disturbance. Quarterly Review of Biology 64:393-418.
POLUNIN, N. 1948. Botany of the Canadian Eastern Arctic, Part 3. Vegetation and ecology. Bulletin No. 104. Ottawa: National Museum of Canada. 304 p.

PORSILD, A.E., and CODY, W.J. 1980. Vascular plants of continental Northwest Territories, Canada. Ottawa: National Museums of Canada. 667 p.

PORSILD, M.P. 1932. Alien plants and apophytes of Greenland. Meddelelser om Grønland 92(1). 85 p.

READER, R.J. 1991. Relationship between seedling emergence and species frequency on a gradient of ground cover density in an abandoned pasture. Canadian Journal of Botany 69:1397-1401.

RYSER, P. 1993. Influences of neighboring plants on seedling establishment in limestone grassland. Journal of Vegetation Science 4:195-202.

SCHLEDERMANN, P. 1976. The effect of climatic/ecological changes on the style of Thule culture winter dwellings. Arctic and Alpine Research 8:37-47.

SCHLEDERMANN, P., and NASH, R.J. 1977. Archaeological overview of the regions along the proposed Polar Gas pipeline route. Prepared for Polar Gas Project by the Arctic Institute of North America, Calgary. 21-23.

SCHOFIELD, W.B., and CODY, W.J. 1955. Botanical investigations on coastal southern Cornwallis Island, Franklin District, N.W.T. Canadian Field-Naturalist 69:116-129.

SHELDRICK, B.H., ed. 1984. Analytical methods manual. Ottawa: Agriculture Canada, Research Branch.

STEERE, W.C. 1953. On the geographical distribution of arctic bryophytes. Stanford University Publications in Biological Sciences 11:30-47.

SVOBODA, J. 1977. Ecology and primary production of raised beach communities, Truelove Lowland. In: Bliss, L.C., ed. Truelove Lowland, Devon Island, Canada: A high arctic ecosystem. Edmonton: University of Alberta Press. 185-216.

- 1982. Due to the Little Ice Age climatic impact most of the vegetative cover in the Canadian High Arctic is of recent origin: A hypothesis (Abstract). Proceedings of the 33rd Alaska Science Conference, September 1982, Fairbanks.

TEERI, J.A., and BARRETT, P.E. 1975. Detritus transport by wind in a high arctic terrestrial ecosystem. Arctic and Alpine Research 7:387-391.

TER BRAAK, C.J.F. 1987. The analysis of vegetation-environment relationships by canonical correspondence analysis. Vegetatio 69:69-77.

. 1990. Update notes: CANOCO ${ }^{\mathrm{TM}}$ version 3.10. Wageningen: Agricultural Mathematics Group. 35 p.

. 1991. CANOCO ${ }^{\mathrm{TM}}$ : A FORTRAN program for canonical community ordination by [partial] [detrended] [canonical] correspondence analysis, principal components analysis and redundancy analysis. Version 3.11. Wageningen: Agricultural Mathematics Group.

THANNHEISER, D. 1989. Eine landschaftsökologishe Detailstudie des Bereichs der Prä-Dorset Station Umingmak (Banks Island, Kanada). Polarforschung 59:61-78.

THOMSON, J.W. 1990. Lichens in the Canadian Arctic Islands. In: Harington, C.R., ed. Canada's missing dimension: Science and history in the Canadian Arctic Islands, Vol. 1. Ottawa: Canadian Museum of Nature. 385-420. 
TREUDE, E. 1977. Pond Inlet, northern Baffin Island: The structure of an Eskimo resource area. Polar Geography 1:95-122.

VAN ANDEL, J., and VAN DEN BERGH, J.P. 1987. Disturbance of grasslands: Outline of the theme. In: Van Andel, J., Bakker, J.P., and Snaydon, R.W., eds. Disturbance in grasslands: Causes, effects and processes. Dordrecht: Kluwer Academic. 3-13.

VAN DER KNAPP, W.O. 1985. Human influence on natural arctic vegetation in the 17 th century and climatic change since A.D. 1600 in northwest Spitsbergen: A paleobotanical study. Arctic and Alpine Research 17:371-387.

VAN DER MAAREL, E. 1979. Transformation of coverabundance values in phytosociology and its effects on community similarity. Vegetatio 39:97-114.

VAN GROENEWOUD, H. 1992. The robustness of Correspondence, Detrended Correspondence, and TWINSPAN Analysis. Journal of Vegetation Science 3:239-246.

VITT, D.H. 1975. A key and synopsis of the mosses of the northern lowlands of Devon Island, N.W.T., Canada. Canadian Journal of Botany 53:2158-2197.

VITT, D.H., and PAKARINEN, P. 1977. The bryophyte vegetation, production, and organic compounds of Truelove Lowland. In:
Bliss, L.C., ed. Truelove Lowland, Devon Island, Canada: A high arctic ecosystem. Edmonton: University of Alberta Press. $225-244$.

WALKER, E.H. 1946. Additional introduced plants in the Aleutian Islands. Bulletin of the Torrey Botanical Club 73:204-205.

WALKER, M.D., DANIËLS, F.J.A., and VAN DER MAAREL, E. 1994. Circumpolar arctic vegetation: Introduction and perspectives. Journal of Vegetation Science 5:758-764.

WEIN, R.W., and RENCZ, A.N. 1976. Plant cover and standing crop sampling procedures for the Canadian High Arctic. Arctic and Alpine Research 8:139-150.

WESTHOFF, V., and VAN DER MAAREL, E. 1978. The BraunBlanquet approach. In: Whittaker, R.H., ed. Ordination and classification of communities. The Hague: Dr. W. Junk. 619726.

ZUTTER, C.M. 1992. Icelandic plant and land-use patterns: Archaeobotanical analysis of the Svalbard midden (6706-60), northeastern Iceland. In: Morris, C.D., and Rackham, D.J., eds. Norse and later settlement and subsistence in the North Atlantic. Glasgow: Department of Archaeology, University of Glasgow. $139-148$ 